\title{
Právo obchodních společností po vstupu České republiky do Evropské unie
}

\author{
Jan Pavlok ${ }^{l}$
}

\section{I. Úvod}

Základní úkoly evropského společenství jsou definovány v čl. 2 Smlouvy o založení Evropského společenství (v současném znění). Jde především o podporu harmonického, vyváženého a trvale udržitelného rozvoje hospodářského života, vysoké úrovně zaměstnanosti a sociální ochrany, rovného zacházení mužů a žen, trvale udržitelné neinflačního růstu, vysokého stupně konkurenční schopnosti a konvergence ekonomické výkonnosti, vysoké úrovně ochrany zlepšování kvality životního prostředí, zvyšování životní úrovně a kvality života, hospodářské a sociální soudržnosti a solidarity mezi členskými státy. Plnění těchto úkolů má být dosaženo vytvořením společného trhu a hospodářské a měnové unie a prováděním společných politik nebo činností.

$\mathrm{Z}$ výše uvedeného vymezení úkolů Evropského společenství a prostředků, jimiž má být splnění těchto úkolů dosahováno je zřejmé, že mimořádný význam má vytvoření společného trhu. Společný trh je založen na celní unii členských států, svobodě volného pohybu zboží, osob, služeb, kapitálu a plateb, dále na společných pravidlech hospodářské soutěže a také na měnové unii. Volný pohyb osob zahrnuje také, kromě volného pohybu zaměstnanců i svobodu usazování, tj. volný pohyb podnikatelských subjektů.

Právní úprava poměrů podnikatelských subjektů je upravena především vnitrostátním právem jednotlivých členských států společenství. V situaci, kdy existuje společný trh založený na výše uvedených prvcích, je nezbytné, aby i právní úprava právních poměrů podnikatelských subjektů, zejména obchodních společností překonala úzké meze právního partikularizmu a získala komunitární dimenzi.

Proto společenství i jednotlivé členské státy věnují již po řadu desetiletí velkou pozornost sblížení úpravy práva obchodních společností. Sbližování práva v této významné právní oblasti je zajištováno trojím způsobem, a to vzájemným uznáváním existence obchodních společností zrrízených v jednom členském státě ostatními členskými státy. Princip vzájemného uznávání obchodních společností je metodou především mezinárodněprávní.

Dále je sblížení právní úpravy obchodních společností zajištováno metodou harmonizace této oblasti práva jednotlivých členských států. Metoda harmonizace je uskutečňována vydáváním směrnic, jejichž implementací jednotlivé členské státy vzájemně přizpůsobí vnitrostátní právo. V oblasti práva obchodních společností je tato metoda nejvýznamnější. Členské státy se postupně sjednotily v názorech na celou řadu důležitých dílčích otázek týkajících se obchodních společností (např. publicita údajů obchodních společností a jejich poboček, kapitál obchodních společností, vnitrostátní fúze a rozdělení obchodních společností, existence společnosti s ručením omezeným o jediném společníku, některé aspekty účetnictví obchodních společností). Některé důležité otázky však dosud zůstaly nevyřešeny

1 JUDr. Jan Pavlok, Katedra podnikového a evropského práva Fakulty mezinárodních vztahů Vysoké školy ekonomické v Praze. 
a jejich harmonizace přes její potřebnost dosaženo nebylo. Jde např. o otázky struktury akciové společnosti, přes hraniční fúze a rozdělení společností, úpravu kartelového práva.

Konečně třetí metodou sbližování právní úpravy obchodních společností je metoda unifikace realizovaná nařízeními. Tato metoda se však neuplatňuje univerzálních způsobem, naopak je jí používáno v případech úpravy speciálních otázek. Za použití této metody byly upraveny zvláštní druhy komunitárních podnikatelských subjektů jako je především evropská akciová společnost a dále evropské hospodářské zájmové sdružení a evropské družstvo.

Chceme-li proto získat důkladnou znalost práva obchodních společností uplatňujícího se na území Evropských společenství a Evropské unie, musíme především studovat právo jednotlivých členských států včetně vnitrostátních norem mezinárodního práva soukromého upravujících kolizní normy. Zároveň však je potřeba i znát především unifikovanou právní úpravu provedenou komunitárním právem za použití nařízení.

\section{Harmonizovaná právní úprava}

\section{1. směrnice}

První směrnice (směrnice Rady č. 68/151 z 9. 3. 1968, o publicitě údajů obchodních společností).

Tato směrnice byla vydána na základě zmocnění obsaženého v čl. 54 odst. 3 písm. g) tehdy platného znění Smlouvy o založení EHS (nyní čl. 44 odst. 2 písm. g Smlouvy o ES). Její vydání také souviselo s Všeobecným programem na zrušení omezení svobody usazování. Jejím hlavním účelem bylo sjednocení základních rysů právní úpravy ochrany věřitelů (v nejširším slova smyslu) obchodních společností. Tato směrnice se však nevztahuje na všechny obchodní společnosti, ale pouze na společnosti kapitálové, jejichž aktivita často překračuje hranice členského státu k němuž příslušejí.

Taxativní výčet jednotlivých společností upravených vnitrostátním právem jednotlivých členských států je obsažen v čl. 1 směrnice.

Pokud jde o povinné zveřejnění dokumentů a údajů týkajících se výše uvedených společností, je potřeba zveřejnit :

- zakladatelskou listinu a stanovy, pokud jsou vyhotoveny jako samostatná listina;

- jakýkoliv dodatek zakladatelské listiny, resp. stanov;

- prodloužení doby trvání společnosti;

- po každé změně zakladatelské listiny, resp. stanov, úplné znění těchto dokumentů ke dni změny;

- jmenování do funkce, dobu trvání funkčního období a podrobnosti týkající se osob tvořících orgány společnosti :

- zmocnění těchto osob jednat za společnost s třetími osobami včetně právních úkonů;

- jejich účast na řízení a kontrole činnosti společnosti;

- určení zda pověřené osoby jednají každá samostatně nebo musí jednat společně;

- každoročně částku zapsaného základního kapitálu; 
- listiny týkající se finanční situace společnosti požadované směrnicemi upravujícími účetnictví obchodních společností;

- jakoukoliv změnu sídla společnosti;

- zrušení společnosti;

- prohlášení neplatnosti společnosti soudem;

- jmenování likvidátora;

- vymezení pravomocí likvidátora, pokud tyto pravomoci nevyplývají ze stanov společnosti;

- ukončení likvidace a výmaz z rejstř́ku, pokud podle práva členského státu zakládá výmaz právní účinky.

V každém členském státě musí být zřízen veřejný registr obchodních společností. Každá společnost musí mít v tomto registru otevřenou samostatnou složku.

V souvislosti s rozvojem techniky přenosu a uchovávání dat směrnice zavádí povinnost vést veřejné registry obchodních společností také $\mathrm{v}$ elektronické podobě, a to s účinností od 1.1.2007. Po tomto datu bude každý oprávněn požádat veřejný registr elektronicky nebo písemně o poskytnutí údajů s tím, že tyto údaje podle volby žadatele budou poskytnuty v elektronické podobě nebo písemně.

Členské státy jsou povinny zajistit zpracování písemných dokumentů založených před 1. 1. 2007 do elektronické podoby s tím, že tato povinnost musí být splněna do 10 let.

Podle této směrnice se dokumenty a údaje týkající se obchodních společností vedou v úředním jazyce státu, kterého se týkají. Dále je možné také dokumenty zakládat v překladu do jiných jazyků.

Směrnice obsahuje podrobná pravidla pro řešení případných rozporů mezi údaji zapsanými v registru a údaji zveřejněnými v oficiální tiskovině. Rovněž tak řeší směrnice rozpor mezi údaji obsaženými v dokumentech vedených $\mathrm{v}$ úředním jazyce a v dokumentech přeložených do jiného než úředního jazyka.

Směrnice také zavádí minimální pravidla pro závaznost jednání před vznikem společnosti. Úprava vychází z toho, že zavázán je ten, kdo za společnost před jejím vznikem jednal. Pokud jednalo více osob jsou tyto osoby zavázány společně a nerozdílně. Schválí-li společnost po svém vzniku jednání zakladatelů před vznikem společnosti, platí, že společnost je zavázána od počátku. Neschválí-li společnost výše uvedená jednání, zůstávají zavázány osoby, které jednaly.

Dále také směrnice určuje závaznost jednání statutárního orgánu společnosti za společnost navenek. Pro jednání statutárního orgánu společnosti neplatí žádné omezení přijatá valnou hromadou nebo jakýmkoliv jiným způsobem, a to ani tehdy když tato omezení byla zveřejněna, a když o nich třetí osoba byla informována. Společnost zavazují jednání statutárního orgánu překračující předmět činnosti společnosti. Jediným omezujícím limitem je př̀kročení pravomoci statutárního orgánu jako takového.

Třetí důležitou otázkou, kterou se směrnice zabývá je otázka neplatnosti společnosti. Neplatnost společnosti je možné prohlásit pouze soudním rozhodnutím, a to na základě taxativně vymezených důvodů uvedených ve směrnici a v časově omezené lhůtě. 
Pokud jde o konkrétní důvody neplatnosti, jde o situaci, kdy :

- nebyla vyhotovena zakládací listina společnosti nebo nebyla pořízena v požadované právní formě;

- předmět činnosti společnosti je protiprávní nebo v rozporu s veřejným pořádkem;

- zakládací listina společnosti nebo stanovy neobsahují obchodní firmu společnosti, určení výše vkladů jednotlivých společníků do základního kapitálu společnosti, výši zapisovaného základního kapitálu společnosti nebo předmět činnosti společnosti;

- základní kapitál společnosti byl stanoven v zakladatelské listině v rozporu s právem členského státu v nižši částce než podle vnitrostátního práva má být;

- žádný ze zakládajících společníků společnosti není způsobilý k právním úkonům;

- v rozporu s vnitrostátním právem počet zakládajících členů společnosti je nižší než 2 .

\section{2. směrnice}

Druhá směrnice (směrnice Rady č. 77/91 ze 13. 12. 1976, o kapitálu obchodních společností).

Důvodem vydání této směrnice byla především ochrana věřitelů společnosti v širším slova smyslu a potřeba harmonizovat ochranu těchto osob ve vnitrostátním právu jednotlivých členských států.

V prvém článku směrnice vymezuje rozsah své působnosti a podává taxativní výčet jednotlivých typů společnosti podle jednotlivých právních řádů členských států. Na rozdíl od prvé směrnice se tato směrnice vztahuje výlučně na akciové společnosti. Členské státy mají možnost nepoužít této směrnice na investiční společnosti a na společnosti družstevního charakteru.

Zakladatelská listina, resp. stanovy společnosti musí vždy obsahovat následující údaje:

- typ a obchodní jméno společnosti;

- předmět činnosti společnosti;

- částku zapsaného základního kapitálu;

- pravidla pro jmenování členem orgánům společnosti jednající za společnost navenek a kontrolních orgánů;

- dobu trvání společnosti.

Dále se v zakladatelské listině nebo ve stanovách musí objevit informace o následujících skutečnostech :

- místo sídla společnosti;

- jmenovitá hodnota akcií společnosti a jejich počet;

- počet akciích bez stanovení hodnoty, jestliže vydání takových akcií je př́ípustné podle vnitrostátního práva;

- zvláštní podmínky pro omezení převodu akcií; 
- v př́ípadě existence několika druhů akcií informace o každém druhu a dále rozsah práv spojených s jednotlivými druhy akcií;

- údaj o tom, zda se jedná o akcie na jméno nebo na doručitele;

- částka upsaného základního kapitálu splaceného v době vzniku společnosti;

- náklady spojené se založením a vznikem společnosti.

Dále směrnice upravuje jednání zakladatelů před vznikem společnosti a situaci, kdy počet společníků společnosti klesne pod minimum stanovené vnitrostátním právem. Tato skutečnost však nesmí vést $\mathrm{k}$ automatickému zrušení společnosti. Naopak soud projednávající případný návrh na zrušení společnosti musí poskytnout společnosti přiměřenou lhůtu $\mathrm{k}$ odstranění protiprávního stavu. Teprve nedojde-li $\mathrm{k} v$ přiměřené lhůtě $\mathrm{k}$ odstranění protiprávního stavu bude společnost zrušena a vstupuje do likvidace.

Pokud jde o minimální výši základního kapitálu, směrnice stanoví její spodní hranici částkou 25000 EUR. Pokud jde o upsaný základní kapitál, může být splacen pouze vklady majícími pro společnost hospodářský význam. Je výslovně zakázáno plnit vklad do základního kapitálu společnosti poskytnutím výkonů nebo služeb.

Prodejní cena jednotlivých akcií nesmí být nižší než jejich nominální hodnota. Před vznikem společnosti musí být splaceno minimálně $25 \%$ nominální hodnoty všech upsaných akcií. Pro případ, že nominální hodnota akcií není stanovena, je třeba splatit před vznikem společnosti $25 \%$ jejich účetní hodnoty. Jsou přípustné i vklady nepeněžité. Pokud jde o nepeněžité vklady, tyto musí být oceněny na společnosti nezávislým znalcem.

Pro př́ípad, že společnost se dostane do ztráty ve vztahu k výše upsanému základnímu kapitálu musí být svolána valná hromada společnosti, a to v přiměřené lhůtě stanovené vnitrostátním právem. Ztráta se považuje za vážnou, pokud je vyšší než polovina upsaného základního kapitálu.

Akciová společnost zásadně nemůže sama nabývat svých vlastních akcií. Za nabytî vlastních akcií společností se považuje i situace, kdy tyto akcie získá osoba odlišná od společnosti jednající vlastním jménem, avšak na účet společnosti. Totéž platí získá-li akcie společnosti společnost jí ovládající. Pokud jde o podmínky nabytí vlastních akcií společností :

- o nabytí vlastních akcií musí rozhodnout valná hromada společnosti s tím, že stanoví podmínky nabytí, počet nabývaných akcií, dobu nabytí akcií (tato doba nesmí být delší než 18 měsíců) a pro př́ípad úplatného nabytí vlastních akcií i maximální a minimální cenu pro nabytí;

- součet nominální hodnoty, resp. účetní hodnoty akcií nesmí přesáhnout $10 \%$ hodnoty upsaného základního kapitálu;

- vlastní kapitál nesmí klesnout pod hodnotu součtu upsaného kapitálu a rezervních fondů, které nejsou určeny pro rozdělení akcionářů;

- společnost může nabývat pouze akcie, jejichž nominální hodnota je zcela splacena.

Rozhodnutí valné hromady společnosti o nabývání vlastních akcií společností není potřeba za situace, kdy společnosti hrozí vážná újma, jejímuž vzniku lze zabránit právě nabytím vlastních akcií. Statutární orgán však musí o podmínkách nabytí vlastních akcií společností podrobně informovat nejbližší následující valnou hromadu. 
Členský stát je oprávněn ve svém vnitrostátním právu upravit i nabývání vlastních akcií společností za účelem jejich převodu na zaměstnance společnosti. $V$ tomto př́ípadě nemusí být dodrženy výše uvedené podmínky pro nabývání vlastních akcií. Společnost však musí převést vlastní akcie na zaměstnance nejpozději do 12 měsíců od jejich nabytí.

Pokud společnost nabude vlastní akcie v rozporu s podmínkami stanovenými ve směrnici, je povinna zbavit se jich nejpozději do 1 roku od jejich nabytí.

Pokud společnost drží vlastní akcie, má pozastaven výkon hlasovacího práva a musí vytvářet zvláštní rezervní fond.

\section{3. směrnice}

Třetí směrnice (směrnice Rady č. 78/855 z 9. 10. 1978, o fúzích obchodních společností).

Tato směrnice upravuje problematiku fúzí obchodních společností. Podle podrobného vymezení rozsahu své působnosti v článku I. se směrnice vztahuje pouze na akciové společnosti a upravuje pouze fúze společností uvnitř jednotlivých členských států. Směrnice se nevztahuje na přeshraniční fúze.

Směrnice rozeznává tři druhy fúzí, a to fúzi se vznikem nové nástupnické společnosti, fúzi slučovaných společností již existující nástupnickou společností a fúzi převzetí jmění zrušené společnosti většinovým společníkem s podílem na zrušené společnosti větším než $90 \%$.

Pokud jde o fúzi se vznikem nové nástupnické společnosti, jde o situaci, kdy před okamžikem fúze existující obchodní společnosti splývají, fúzí dochází k zániku jejich právní subjektivity a nástupnickou společností se současně s okamžikem jejich zániku stává nově vzniklá nástupnická společnost.

Při fúzi sloučením sice také zanikají původní slučované společnosti až na jednu z nich, která zároveň je společností nástupnickou. Nástupnická společnost tedy existuje před okamžikem fúze, tak po něm, je zachována její základní identita, avšak mění se rozsah jejího jmění a složení společníků.

$V$ případě převzetí jmění většinovým společníkem jde o fúzi, kdy existující obchodní společnost je zrušena, nevstupuje však do likvidace, její jmění přebírá a právním nástupcem se stává většinový společník této společnosti. Tento způsob fúze je však možný pouze v případě, kdy většinový společník má ve zrušené společnosti větší podíl než $90 \%$.

Směrnice podrobně upravuje proces př́ípravy fúzí i jejich provedení. Důraz klade na podrobné zpracování návrhu fúze, jeho zdůvodnění, zveřejnění, umožnění společníků všech zúčastněných společností seznámit se s návrhem fúze a zachování zásadně stejného postavení všech společníků všech zúčastněných společností před fúzí i po fúzi. Patřičný důraz je také kladen na řádné zajištění postavení všech věritelů fúzujících společnostív širším slova smyslu. Náležitá pozornost je věnována také výměnnému poměru akcií, resp. podílů před fúzí a po fúzi. Zásadně má být zachováno stejné postavení s tím, že případný rozdíl, avšak nejvýše do objemu $10 \%$ původního podílu může být vyrovnán v penězích.

Dále směrnice upravuje publicitu údajů týkajících se fúzí, právní následky fúze, odpovědnost funkcionářů fúzujících společností a znalců posuzujících fúzi za porušení povinností při jejich činnosti. Směrnice také upravuje podmínky pro př́ípadnou neplatnost fúze, která může být vyslovena pouze rozhodnutím soudu. 


\section{6. směrnice}

Šestá směrnice (směrnice Rady č. 82/891 ze 17. 12. 1982, týkající se rozdělení obchodních společností).

Tato směrnice navazuje na třetí směrnici o fúzích obchodních společností a upravuje opačný postup, tj. rozdělení společnosti na více nástupnických společností, a to různými způsoby. Směrnice rozlišuje dva základní způsoby rozdělení, a to rozdělení stávající společnosti sloučením do již existujících nástupnických společností a dále rozdělení stávající společnosti do nově vzniklých nástupnických společností. Směrnice také upravuje zvláštní případ rozdělení společnosti pod dohledem soudu.

Směrnice podobně jako směrnice o fúzích obchodních společností podrobně upravuje postup při rozdělení společnosti. Rovněž v tomto případě je potřeba vypracovat návrh rozdělení. Tento návrh musí být $\mathrm{v}$ dostatečném časovém rozvrhu zveřejněn, tak aby se s ním mohl seznámit všichni společníci všech zúčastněných společností. Směrnice věnuje velkou pozornost tomu, aby výměnný podíl akcií, resp. podílů, a aby bylo zajištěno stejné postavení všech společností před rozdělením i po rozdělení společnosti. I u rozdělení je možné dorovnání rozdílů ve výměnném poměru akcií v penězích, avšak nejvíce do objemu $10 \%$ vyměňovaného podílu.

I u rozdělení musí být řádně chráněni věřitelé společnosti v širším slova smyslu. Také je potřebné odborné posouzení návrhu rozdělení znalci.

\section{1. směrnice}

Jedenáctá směrnice (směrnice Rady č. 89/666 z 21. 12. 1989, o požadavcích na zveřejnění údajů týkajících se poboček zřízených v členských státech obchodními společnostmi ř́dícími se právem jiného členského státu).

Jedenáctá směrnice velmi úzce souvisí s prvou směrnicí (směrnice č. 68/151) o publicitě údajů obchodních společností. Zatímco prvá směrnice upravuje problematiku týkajícíse obchodních společností a údajů, které tyto společnosti povinně zveřejní, jedenáctá směrnice řeší tentýž problém, pokud jde o pobočky obchodních společností.

Tato směrnice má dvě základní části. V prvé části upravuje publicitu údajů a dokumentů týkajících se poboček zřízených společnostmi, které samy mají registrované sídlo v některém z členských států EU.

Konkrétně jsou tyto údaje uvedeny v článku 2 citované směrnice. Povinné zveřejnění zahrnuje :

- adresu pobočky;

- předmět činnosti pobočky;

- registrační údaje týkající se společnosti, která pobočku zřídila;

- obchodní firmu a právní formu společnosti a dále jméno pobočky, pokud se liší od obchodní firmy společnosti;

- jmenování funkčního období a osobní údaje vedoucího pobočky;

- zrušení společnosti, jmenování likvidátorů, osobní údaje likvidátorů, jejich pravomoci, ukončení likvidace;

- prohlášení konkurzu nebo obdobné situace; 
- účetní dokumenty (v souladu se 4 a 7 směrnicí);

- uzavření pobočky.

Právní řád členského státu, ve kterém pobočka byla otevřena může stanovit zveřejnění dalších údajů a dokumentů, např. podpisového vzoru vedoucího pobočky, zakladatelské dokumenty apod.

V druhé části 11 směrnice upravuje publicitu údajů, pokud jde o pobočky společností majících sídlo ve třetích státech. V tomto směru je směrnice přísnější a ukládá členským státům upravit ve vnitrostátním právu podrobnosti zveřejňování údajů a dokumentů poboček zřízených společnostmi ze třetích států více povinností, než je tomu u společností se sídlem na území členských států.

Zveřejňují se tyto údaje :

- sídlo pobočky;

- předmět činnosti pobočky;

- právní řád, kterým se řídí společnost, která pobočku otevřela;

- údaj o registru, ve kterém je taková společnost zapsána a registrační číslo společnosti v tomto registru;

- zakladatelská listina, stanovy společnosti, pokud jsou na samostatné listině;

- právní forma společnosti, hlavní místo její činnosti, předmět činnosti, výše základního kapitálu;

- obchodní firma společnosti a označení pobočky, pokud se od obchodní firmy liší;

- jmenování funkcionářů a skončení výkonu funkce, osobní údaje osob, které jsou oprávněny za společnost jednat navenek;

- zrušení společnosti, jmenování likvidátorů, ukončení likvidace;

- prohlášení konkurzu;

- účetní dokumenty;

- uzavření pobočky.

Ve své třetí části směrnice vymezuje povinnost společnosti, která zřizuje povinnost uvést údaje o této pobočce a jejím hospodaření do výroční zprávy společnosti. Pokud jde o podrobnosti obsahu výroční zprávy odkazuje směrnice na čtvrtou směrnici o účetních závěrkách.

\section{2. směrnice}

Dvanáctá směrnice (směrnice Rady č. 89/667 z 21. 12. 1989, o společnostech s ručením omezeným s jediným společníkem).

Tato směrnice byla vydána především proto, že bylo potřeba poskytnout záruky a ochranu zájmů.

Pokud jde o společnosti s ručením omezeným s jediným společníkem bylo potřeba reflektovat několik důležitých okolností. 
Před přijetím této směrnice neexistovaly v právních řádech jednotlivých členských států základní standardy ochrany věritelů společností s. r.o. s jediným společníkem. Potřeba harmonizovat tuto oblast práva se ukázala matnou.

Rozvinutá harmonizace práva již existovala, pokud šlo o společnosti akciové. Zejména se jednalo o směrnice 68/151 (publicita), 77/91 (kapitál), 78/855 (fúze), 82/891 (rozdělení) a dále směrnice 78/660 (účetní závěrka).

Dalším důležitým důvodem pro harmonizaci byla také ta skutečnost, že některé členské státy přijaly úpravu umožňující existenci s.r.o. s jediným společníkem, kdežto právo některých dalších členských států to neumožňovalo. Nemalou roli sehrála i Rezoluce Rady ze dne 3. 11. 1986, kterou byl přijat akční program pro malé a stř̌ední podniky.

Společnost může být založena jediným zakladatelem. Může však se stát společností s jediným společníkem i během své existence tím, že obchodní podíly se soustředív rukou jediného společníka.

Členské státy mohou přijmout vnitrostátní úpravu (včetně sankcí) pro situace, že fyzická osoba je jediným společníkem ve více společnostech nebo, že společnost s jediným společníkem je jediným společníkem jiné společnosti.

Nastane-li situace, že spol. s r.o. se stane společností s jediným společníkem, musí taková změna být zaznamenána ve veřejném registru společností př́stupném veřejnosti. Zveřejněna musí být i totožnost takového společníka.

Jediný společník v takové společnosti vykonává pravomoc valné hromady společnosti. Rozhodnutí takového společníka přijatá při výkonu pravomoci valné hromady musí být zachycena v písemné formě.

Rovněž smlouvy sjednávané mezi společníkem jako takovým na straně jedné a společností jím reprezentovanou na straně druhé musí být uzavřeny písemně. Členské státy mohou ve své právní úpravě upustit od požadavku písemné formy v těch případech, kdy se jedná o smlouvy uzavírané za obvyklých obchodních podmínek.

Pokud právní řád členského státu umožňuje existenci akciové společnosti s jediným akcionářem, použijí se pravidla upravená 12. směrnicí také na tento typ obchodních společností.

\section{4., 7. a 8. směrnice}

Čtvrtá, sedmá a osmá směrnice (směrnice Rady č. 78/660 ze 25. 7. 1978, o účetních závěrkách obchodních společností, směrnice Rady č. 83/349 z 13. 6. 1983, o konsolidovaných účetních závěrkách a směrnice Rady č. 84/253 z 10. 4. 1984, o auditorech).

Všechny tři tyto směrnice poměrně značně podrobně a obsáhle upravují náležitosti účetní závěrky a účetních podrobností s účetní závěrkou související u kapitálových obchodních společností s tím, že jsou použitelné i na společnosti osobní. Čtvrtá směrnice se zabývá účetními závěrkami, sedmá směrnice se zabývá stejnou problematikou z pohledu konsolidace a osmá směrnice upravuje postavení a význam auditu a dále postavení auditorů a jejich odpovědnost. Osmá směrnice zejména zdůrazňuje nutnost povinného auditu účetních společností nezávislým auditorem jako odborníkem v nezávislém postavení. Je však třeba důrazně upozornit na tu skutečnost, že výše uvedené směrnice nelze v žádném případě považovat za účetní standardy. 
Kromě výše zmíněných směrnic se účetní a daňovou problematikou obchodních společností zabývají ještě další normy sekundárního komunitárního práva. Jde o směrnice č. 90/434, o společném systému zdanění použitelném na fúze rozdělení, převody podílů a výměny akcií týkající se společností z různých členských států, č. 90/435, o společném systému zdanění použitelném na případy mateřských a dceřiných společností z různých členských států, č. 2003/49, o společném systému zdanění použitelném na úroky a výnosy převáděné mezi spojenými společnostmi z různých členských států, nařízení č. 1606/2002, o aplikaci mezinárodních účetních standardů a nařízení č. 1725/2003, o prijietí určitých mezinárodních účetních standardů podle nařízení č. 1606/2002.

Podrobnější rozbor těchto směrnic by však přiliš zacházel do úzce odborné problematiky účetnictví a daní a byl by nad rámec předmětu tohoto článku.

Přehled jednotlivých směrnic tak, jak je výše uveden je popisem současného stavu právní úpravy práva obchodních společností. Všechny výše uvedené směrnice byly vydány v rámci regulérního legislativního procesu, nabyly řádně účinnosti a byly implementovány do vnitrostátního práva obchodních společností jednotlivých členských států. Je však důležité také se zmínit o osudu a obsahu směrnic, které byly vypracovány pouze v návrhu, avšak členské státy nedospěly $\mathrm{k}$ dohodě o jejich obsahu. Tyto směrnice se dosud nestaly součástí komunitárního práva a s ohledem na značné názorové rozdíly jednotlivých členských států není př́liš velká naděje, že by se situace někdy změnila.

V prvé řadě jde o návrh páté směrnice o struktuře akciové společnosti. Problematika struktury akciové společnosti je velmi důležitá a bylo by velmi žádoucí, aby okruh otázek týkajících se struktury akciové společnosti se stal součástí komunitárního práva. Návrh směrnice již byl několikrát předložen k přijetí, poprvé v roce 1959 později v letech 1972, 1983 a 1991. Členské státy se nemohou shodnout na pojetí ŕídících orgánů akciové společnosti a na účasti zaměstnanců na řízení akciové společnosti.

Pokud jde o koncepci řídících orgánů akciové společnosti, existují dva modely řešení. První model, také nazývaný monistický vychází z pojetí jediného řídícího orgánu akciové společnosti podřízeného nejvyššímu orgánu, tj. valné hromadě. Dualistický model naopak vychází z existence samostatného řídícího orgánu a samostatného kontrolního orgánu s tím, že kontrolní orgán je oprávněn kontrolovat řídící orgán a oba tyto orgány jsou podřízeny přímo valné hromadě společnosti. Právní úprava některých členských států pak umožňuje i situaci, kdy kontrolní orgán jmenuje a odvolává členy řídícího orgánu.

Ohledně účasti zaměstnanců na řízení akciové společnosti rovněž existují dva zásadně rozdílné názory. Prvý názor je založen na široké účasti zaměstnanců na řízení akciové společnosti, zejm. prostř̌ednictvím dozorčího orgánu. Druhý názor naopak účast zaměstnanců na řízení akciové společnosti zcela odmítá.

Návrh deváté směrnice se zabýval koncernovým právem. Upravoval postavení tzv. faktického koncernu a koncernu smluvního. Předpokládaná právní úprava byla velmi podrobná a návrh byl inspirován zejména německým koncernovým právem. Návrh této směrnice byl odmítnut pro př́lišnou podrobnost a příliš regulativní přístup. 


\section{Unifikovaná právní úprava}

Metoda unifikace jako metoda právní úpravy není v oblasti komunitárního práva obchodních společností př́liš často využívána. Pouze v jednotlivých případech byla vydána nařízení, která upravila některé specializované otázky týkající se této právní oblasti. Pokud však jde o existenci podnikatelských subjektů, byla vydána zatím pouze tři nařízení upravující existenci specializovaných podnikatelských subjektů komunitárního typu. Jde o nařízení Rady č. 2137/85 ze dne 25. 7. 1985, o evropském hospodářském zájmovém sdružení, nařízení Rady č. 2157/2001 ze dne 8. 10. 2001, o evropské akciové společnosti a konečně nařízení Rady č. 1435/2003 ze dne 22. 7. 2003, o evropském družstvu. V souvislosti s těmito nařízeními byly přijaty ještě směrnice harmonizující otázku účasti zaměstnancủ na řízení evropské akciové společnosti, resp. evropského družstva.

\section{Evropská akciová společnost}

Existence evropské akciové společnosti byla dlouhou dobu velmi nejistá. Při projednávání opakovaných návrhů nařízení upravujícího její existenci se členské státy nemohly dohodnout. Nakonec však se podařilo dosáhnout shody, která vedla k vydání nařízení Rady č. 2157/2001 ze dne 8. 10. 2001, o evropské akciové společnosti. Toto nařízení nabude účinnosti dne 8. 10. 2004.

Toto nařízení však nezavádí univerzální jednotnou právní úpravu práva akciové společnosti a nenahrazuje $\mathrm{v}$ tomto směru vnitrostátní úpravu provedenou v právních řádech jednotlivých členských států EU. Evropská akciová společnost je speciálním typem obchodní společnosti kapitálové typu, jejíž existence má umožnit podnikání na jednotném společném trhu tomu odpovídajícím typem podnikatelského subjektu komunitárního typu.

Evropská akciová společnost (někdy také Societa Europaea nebo SE) je společností akciového typu, která může být založena kdekoliv na území společenství za podmínek stanovených výše citovaným nařízením. Kapitál společnosti musí být rozdělen do akcií a akcionáři nejsou odpovědni za závazky společnosti. Evropská akciová společnost má právní subjektivitu.

Evropská akciová společnost nemůže být založena způsobem obvyklým u běžného typu akciové společnosti. V jejím případě jde vždy o tzv. derivativní způsob založení již existující akciovou společností, resp. společnostmi registrovanými na území členského státu, resp. nejméně dvou členských států EU.

Pokud jde o jednotlivé způsoby založení evropské akciové společnosti, jde o tyto :

- evropská akciová společnost může být založena nejméně dvěma akciovými společnostmi zrrízenými podle právního řádu některého z členských států EU se sídlem zapsaným na území společenství s tím, že alespoň dvě zakládající akciové společnosti musí mít své sídlo zapsáno v různých členských státech;

- evropská akciová společnost může být dále založena tak, že akciové společnosti založené podle práva členských států se sídlem zapsaným v alespoň dvou rozdílných členských státech vytvoří evropskou akciovou společnost jako společnost holdingovou. Pokud by zakladatelem holdingové společnosti byla jediná akciová společnost musí mít po dobu nejméně dvou let před založení evropské akciové společnosti jako společnosti holdingové dceřinou společnost nebo pobočku zříze- 
nou podle práva jiného členského státu se sídlem zapsaným na území jiného členského státu;

- evropská akciová společnost může být dále založena také tak, že nejméně dvě akciové společnosti založené podle práva některého z členských států se sídlem v různých členských státech založí evropskou akciovou společnost jako společnost dceřinou. Pokud by zakládající mateřskou společností byla pouze jediná akciová společnost musí tato mateřská společnost mít jinou dceřinou společnost nebo pobočku zapsanou podle práva jiného členského státu na jeho území po dobu nejméně dvou let před založením evropské akciové společnosti;

- evropská akciová společnost může být založena také tak, že již existující akciová společnost založená podle práva některého z členských státu se sídlem zapsaným na jeho území změní svoji právní formu $\mathrm{z}$ akciové společnosti založené podle vnitrostátního právního řádu na evropskou akciovou společnost založenou podle tohoto nařízení. Tuto možnost má však pouze opět jako ve výše uvedených případech akciová společnost mající v jiném členském státě dceřinou společnost nebo pobočku po dobu nejméně dvou let;

- členský stát může ve svém právním řádu upravit možnost založení evropské akciové společnosti také tak, že evropská akciová společnost bude založena akciovou společností založenou podle práva členského státu se sídlem zapsaným na jeho území, avšak s hlavní správou umístěnou mimo území společenství, pokud tato společnost má skutečný a dlouhodobý vztah s ekonomikou tohoto členského státu.

Základní kapitál evropské akciové společnosti musí minimálně činit 120000 EUR a být také v této měně vyjádřen. Pokud právní řád některého členského státu požaduje u akciové společnosti vyšší základní kapitál než je výše uvedená částka, musí tento požadavek vztáhnout i na evropskou akciovou společnost se sídlem zapsaným na jeho území. Pokud jde o ostatní otázky týkající se udržování stanovené výše základního kapitálu, změn jeho výše akcií a jiných cenných papírů vydávaných společností, řídí se právní režim těchto otázek právním řádem státu, na jehož území má evropská akciová společnost zapsané sídlo.

Pokud jde o sídlo evropské akciové společnosti, nařízení stanoví povinnost, aby byl zajištěn soulad mezi místem sídla zapsaného a sídla skutečného. Pokud jde o možnost přeložení zapsaného sídla společnosti z jednoho členského státu společenství do jiného, nařízení takovýto postup umožňuje při zachování identity a právní kontinuity existence evropské akciové společnosti. Při tomto postupu nedochází ke zrušení společnosti v jednom členském státě a k jejímu novému založení a vzniku na území členského státu, do kterého bylo přemístěno její sídlo. Na druhé straně postup při změně sídla evropské akciové společnosti z území jednoho členského státu na území jiného členského státu je předepsán poměrně podrobný právní postup chránící především věřitele společnosti v širším smyslu. Zejména musí být zajištěno splnění všech předepsaných povinností a formalit ve státě původního sídla a teprve potom je možné povolit zápis ve státě nového sídla společnosti.

Pokud jde o právní režim společnosti, řídí se její poměry v prvé řadě výše citovaným nařízením. Pokud v nařízení je výslovně umožněno, aby některá otázka se řídila stanovami platí pravidlo určené stanovami. Otázky, které nejsou upraveny nařízením ani v povoleném rozsahu stanovami společnostmi se řídí ustanoveními právního řádu členského státu, která byla harmonizována komunitárními směrnicemi. Otázky, které nejsou upraveny ani harmonizovaným vnitrostátním právem se řídí vnitrostátním právem členského státu, na jehož území má společnost zapsané sídlo. 
Pokud jde o strukturu evropské akciové společnosti ponechává nařízení na právním řádu členského státu, zda bude použit monistický nebo dualistický způsob řízení akciové společnosti. Nejvyšším orgánem evropské akciové společnosti však vždy je valná hromada.

Nařízení upravuje i základní otázky týkající se účetnictví evropské akciové společnosti, jejího zrušení, vstupu do likvidace, úpadku a některých dalších otázek. Tyto otázky se většinou řídí právním řádem členského státu, na jehož území je zapsáno sídlo evropské akciové společnosti.

Pokud jde o účast zaměstnanců na rrízení evropské akciové společnosti, tuto otázku řeší směrnice vydané v souvislosti s nařízením č. 2001/86 z 8. 10. 2001, o účasti zaměstnanců na řízení evropské akciové společnosti.

\section{Evropské družstvo}

V loňském roce přijala Rada nařízení č. 1435/2003, o evropském družstvu. Toto nařízení umožňuje zřízení zvláštního podnikatelského subjektu družstevního typu. Tato právní úprava však nenahrazuje obecnou úpravu družstva jako podnikatelského subjektu v právních řádech jednotlivých členských států.

Evropské družstvo vytváří povinně základní kapitál, který musí být rozdělen na akcie. $\mathrm{V}$ průběhu existence družstva dochází ke změnám v počtu členů a tím i ve výši kapitálu. Předmětem činnosti družstva není v prvé řadě podnikání za účelem dosahování zisku, ale činnost směřující k uspokojování potřeb členů a činnost rozvíjející jejich hospodářské a sociální aktivity. Evropské družstvo má právní subjektivitu. Účast zaměstnanců družstva na jeho řízení je upravena směrnicí č. 2003/72, o účasti zaměstnanců na řízení družstva.

Družstvo může být založeno pěti nebo více fyzickými osobami z alespoň dvou členských států nebo pěti nebo více fyzickými osobami a právnickými osobami z alespoň dvou členských států nebo společnostmi a jinými právnickými osobami zřízenými podle soukromého nebo veřejného práva členských států z alespoň dvou členských států. Dále může být evropské družstvo založeno fúzí družstev založených podle práva členských států se zapsaným a skutečným sídlem uvnitř společenství, pokud fúzující družstva jsou alespoň ze dvou členských států. Také je možná změna právní formy z družstva založeného podle vnitrostátního práva některého z členských států na evropské družstvo, pokud transformující se družstvo má po dobu alespoň dvou let dceřinou společnost v jiném členském státě. Vnitrostátní právo může umožnit založení evropského družstva také v případě, že by zakladatel měl zapsané sídlo v členském státě, avšak skutečné sídlo mimo území společenství, pokud takovýto subjekt má trvalou vazbu na ekonomiku členského státu.

Pokud jde o kapitál evropského družstva, musí být vyjádřen v národní měně. Pokud jde o družstvo založené v členském státě, který není účastníkem měnové unie, může být kapitál družstva vyjádřen také v EUR. Minimální základní kapitál nesmí být nižší než 30000 EUR. Zapsaný základní kapitál družstva musí být rozdělen do členských akcií vyjádřených ve vnitrostátní měně. Při založení družstva musí být splaceno minimálně $25 \%$ nominální hodnoty upsaných akciís tím, že zbytek této hodnoty musí být splacen do 5 let.

Vnitřní poměry družstva se řídí zakladatelskou listinou a stanovami. Tyto základní dokumenty družstva mohou být pořízení bud' v jedné listině nebo každý samostatně.

Zapsané sídlo družstva musí být umístěno uvnitř společenství, a to v tom samém členském státě, ve kterém je jeho skutečné sídlo. Členský stát může upravit ve svém právním řádu povinnost umístit zapsané sídlo a skutečné sídlo do téhož místa. Nařízení umožňuje změnu sídla družstva z území jednoho členského státu na území jiného. Při této změně ne- 
dochází ke zrušení družstva a jeho nového založení ve státě nového sídla. Naopak je zachována právní kontinuita družstva a jeho totožnost.

Právní poměry evropského družstva se řídí $\mathrm{v}$ prvé řadě výše citovaným nařízením. Dále $\mathrm{v}$ případě, že nařízení to výslovně připouští, řídí se poměry družstva ustanoveními jeho zakladatelské listiny a stanov. Pro případ, že určitá záležitost není upravena v nařízení nebo je-li upravena pouze částečně řídí se právní poměry družstva v této záležitosti vnitrostátním právem členských států harmonizovaným komunitárními směrnicemi a upravujícím poměry družstva.

Nařízení upravuje podrobně celou řadu dalších otázek, např. zápis do obchodního rejstříku a požadavky na zveřejnění údajů týkajících se družstva, zveřejnění dokumentů družstva, otázky vzniku a zániku členství, podrobnosti založení družstva, strukturu orgánů družstva a základní pravidla jejich jednání a rozhodování, odpovědnost funkcionářů družstva, právo členů na informace týkající se družstva, tvorbu rezervního fondu, zrušení družstva, jeho likvidaci, úpravu právních poměrů pro případ úpadku a další.

\section{Evropské hospodářské zájmové sdružení}

Evropské hospodářské zájmové sdružení je samostatným typem podnikatelského subjektu, jehož existenci připouští a upravuje komunitární právo. Právní úprava sdružení je obsažena v nařízení Rady č. 2137/85 ze dne 25. 7. 1985, o evropském hospodářském zájmovém sdružení. Toto nařízení nabylo účinnosti dne 1. 7. 1989.

Účelem existence sdružení je usnadnění a rozvíjení hospodářské činnosti jeho členů. Sdružení může mít nejvýše 500 zaměstnanců, může být založeno nejméně dvěma osobami s tím, že zakladatelé musí mít sídlo alespoň ve dvou členských státech.Účast na sdružení má povahu členského poměru. Toto členství je neomezeně převoditelné. Členy mohou být pouze osoby v nezávislém postavení. Pokud jde o odpovědnost členů za závazky sdružení, tato je solidární a neomezená.

Výše citované nařízení řeší jenom základní otázky existence sdružení a jeho vnitřních poměrů. Celá řada otázek je ponechána na vnitrostátní úpravě s tím, že některé otázky jsou upraveny vnitrostátním právem harmonizovaným směrnicemi a některé právem neharmonizovaným.

\section{Vstup České republiky do evropských společenství a Evrop- ské unie a právo obchodních společností}

V souvislosti se vstupem naší země do evropských společenství a Evropské unie došlo k 1. květnu letošního roku k významné změně našeho právního řádu. Od okamžiku vstupu platí na našem území nadále náš vnitrostátní právní rád a vedle vnitrostátního práva také v plném rozsahu komunitární právo. V oblasti práva obchodních společností to znamená, že jsem povinni se řídit unifikovaným právem obchodních společností. Ke dni našeho vstupu do společenství však platí zatím pouze právní úprava evropského hospodářského zájmového sdružení provedená nařízením Rady č. 2137/85. Pokud jde o evropskou akciovou společnost nabude účinnosti nařízení upravující právní poměry této společnosti, tj. nařízení Rady č. 2157/2001 teprve k 8. 10. 2004. Evropské družstvo budeme moci využívat až od 18. 8. 2006. Teprve k tomuto dni nabude účinnosti nařízení Rady č. 1435/2003.

Pokud jde o oblast harmonizovanou směrnicemi, v tomto směru je právní úprava pro nás aktuální od okamžiku našeho vstupu do společenství. Jedním ze základních požadavků 
pro vstup naší země do evropských struktur byl požadavek sblížení práva. Naše vnitrostátní právní úprava obchodních společností a družstva je obsažena v II. části obchodního zákoníku (\$\$ 56-260). Tato právní úprava byla ve všech základních směrech plně sblížena s komunitárním právem a od 1. 5. 2001 je tedy harmonizována. Teprve budoucí realita hospodářského života a na ni navazující právní praxe a judikatura soudů ukáží nakolik je české právo obchodních společností harmonizováno a kde jsou př́ípadné nedostatky. $\mathrm{V}$ těch případech kde by u jednotlivých dílčích otázek harmonizace našeho práva chyběla nebo by byla provedena nekvalitně, tj. $v$ rozporu s příslušnou směrnicí, bude třeba počítat s přímou aplikovatelností a s přímým účinkem odpovídajících právních norem komunitárního práva. V praxi to může znamenat potřebu obracet se v jednotlivých soudních sporech s předběžnou otázkou na Evropský soudní dvůr.

Vzájemné uznávání existence obchodních společností zřízených podle práva jiného státu je právním prostředkem, který je v našem právu respektován a uplatňován bez zvláštních obtíží.

\section{Literatura}

1. TICHÝ, L. - ARNOLD, R. - SVOBODA, P. - ZEMÁNEK, J.-KRÁL, R.: Evropské právo. 2. vydání. Praha, C. H. BECK, 2004, 919 s.

2. HAKENBERGOVÁ, W. - VĚRNÝ, A.: Základy evropského hospodářského práva. 1. vydání.Praha, C. H. BECK, 2000.

3. TICHÝ L. a kol.: Dokumenty ke studiu evropského práva, 2. vydání. Linde Praha a. s., 2002.

4. BALAŠ, V. - ŠTURMA, P.: Kurs mezinárodního ekonomického práva. 1. vydání. Praha, C. H. BECK, 1997.

5. CIHELKOVÁ, E.: Vnějšš ekonomické vztahy Evropské unie. 1. vydání, Praha, C. H. BECK, 2003.

6. ZAHRADNÍK, P.: Vstup do Evropské unie. Přínosy a náklady konvergence. 1. vydání. Praha, C.H. BECK, 2003.

7. DĚDIČ J. a kol.: Obchodní zákoník, komentár̆ I.-IV. 1. vydání. Praha, Nakladatelství POLYGON, 2002.

8. ŠTENGLOVÁ, I. - PLÍVA, S. - TOMSA, M. a kol:. Obchodní zákoník. Komentář. 8. vydání. Praha, C. H. BECK, 2003, xvi, 1443 s.

9. SALAČ, J.: Perspektivy evropského práva obchodních společností, Právní rozhledy 5/2001, př́iloha Evropské právo, str. 1-4. 